\section{PREPARATION POLYURETHANE COMPOSITES FILLED WITH WASTE CARBON TYRES (WCT) AS GROUTING MATERIAL}

Nur Izzah Atirah Mat Hussainb, Noor Najmi Bonniaa*, Radin Siti Fazlina Nazrah Hirzin ${ }^{b}$, Ernie Suzana Alic, Suzana Ratima

aMaterials Science and Technology Department, Faculty of Applied Sciences, Universiti Teknologi MARA Shah Alam, Malaysia bPolymer Science and Technology Department, Faculty of Applied Sciences, Universiti Teknologi MARA Shah Alam, Malaysia cApplied Physic Department, Faculty of Science and Technology, Universiti Sains Islam, Malaysia
Article history

Received

7 January 2020

Received in revised form

14 May 2020

Accepted

10 June 2020

Published online

27 August 2020

*Corresponding author noornajmi@vitm.edu.my

\begin{abstract}
This research focused on the fabrication of castor-based polyurethane composite (CPUC) filled with waste carbon tyres (WCT) with particle size of $200 \mu \mathrm{m}$ that acts as reinforcing filler. WCT was first sieved using a sieving machine to obtain uniform particle size. WCT loading was varied at $0 w+\%, 2 w+\%, 4 w+\%$ and $6 w+\%$. The effect of WCT loading in CPUC was evaluated based on their foam reaction time, apparent density, rheology, compression strength, morphology and thermal properties. The foam reaction time of CPUC achieved was in the range of industrial PU grout's properties. The rheology index and compression strength of CPUC decreased with increasing WCT loading. CPUC with 2 wt\% of WCT loading achieved the optimum compression strength where it increased from 2.58 MPa to $3.39 \mathrm{MPa}$ with the improvement of $31.40 \%$ compared to neat PU. FESEM micrograph showed that CPUC consists of closed foam cell indicating the rigidity of the CPUC. The addition of 2 wt\% of WCT resulted in achieving the optimum thermal stability of CPUC where CPUC2 had the highest char residue content. The high residue content indicated that CPUC2 had the lowest decomposition of elements as WCT acted as heat barrier in CPUC matrix thus increasing the thermal stability of CPUC2.
\end{abstract}

Keywords: Castor-based polyurethane composite (CPUC), waste carbon tyres (WCT), rheology, compression strength, thermal stability

\begin{abstract}
Abstrak
Kajian ini tertumpu kepada fabrikasi komposit poliuretana berasaskan minyak kastor (CPUC) berpengisi karbon yang dikitar semula daripada tayar buangan dengan saiz $200 \mu \mathrm{m}$ sebagai bahan pengukuhan. Karbon daripada tayar buangan diayak terlebih dahulu dengan menggunakan mesin pengayak untuk mendapatkan saiz zarah WCT yang seragam. Penambahan WCT dibuat pada komposisi yang berbeza iaitu 0wt\% 2wt\%, $4 \mathrm{w}+\%$ dan $6 \mathrm{w}+\%$. Kesan penambahan WCT ke atas CPUC diuji dari segi masa tindak balas pembentukan busa, ketumpatan, reologi, sifat mampatan, sifat morfologi dan sifat terma. Hasil menunjukkan bahawa masa tindak balas busa CPUC seiring dengan sifat bahan turap poliuretana industri. Dari segi indeks reologi dan kekuatan mampatan CPUC, ianya menurun dengan peningkatan kandungan WCT. CPUC dengan 2 wt\% isian WCT mencapai kekuatan mampatan yang paling optimum iaitu meningkat dari $2.58 \mathrm{MPa}$ ke $3.39 \mathrm{MPa}$ dengan peningkatan sebanyak $31.40 \%$ berbanding PU tanpa kandungan WCT. FESEM mikrograf menunjukkan bahawa CPUC mempunyai sel busa tertutup menandakan ketegaran CPUC. Penambahan 2wł\% WCT memberi sifat terma yang paling optimum di mana CPUC2 mempunyai berat sisa yang paling tinggi. Baki berat yang tinggi menunjukkan bahawa CPUC2 mempunyai penguraian unsur yang paling rendah di mana WCT bertindak sebagai penebat haba di dalam CPUC dan menghasilkan peningkatan dalam kestabilan haba CPUC2.

Kata kunci: Komposit poliuretana berasaskan kastor (CPUC), sisa karbon tayar (WCT), reologi, kekuatan mampatan, kestabilan terma
\end{abstract}

(C) 2020 Penerbit UTM Press. All rights reserved 


\subsection{INTRODUCTION}

Nowadays, polymeric materials play important roles in human's daily life and various industries. Polyurethane is one of the most versatile polymer material that has been widely used as coatings, adhesives, foam mattresses, medical implants, insulator and grouting material [1]. Polyurethane as a grouting material has been gaining a lot of attention from manufacturers from all over the world due to its extraordinary properties such as light weight, good permeability and good mechanical performance [2]. Polyurethane grout is a rigid foam material. Due to the formulation development of polyurethane, there is a rising demand for polyurethane grouts as they exhibit excellent mechanical properties which help to improve infrastructures and used to seal many types of leakages [3]. Besides, rigid polyurethane foam is the most suitable material for grouting because it has a good expansion ability, excellent bonding properties and can be cured in a short amount of time [4]. However, polyurethane in its pure form is unable to fulfill the demand in the grouting field which requires a good mechanical and thermal properties of polyurethane grout. Hence, reinforcement is needed to improve the properties of polyurethane grout. There are several factors that need to be considered in choosing the right reinforcement for the polymer such as the cost, chemical composition, density, particle size and thermal properties. This is to ensure that the composites produced fulfill the demands in the particular field. There are many types of reinforcement available in the industry such as silica, carbon black, kaolin, sepiolite and graphene [4]. However, most of these materials are inorganic which made them incompatible with organic polyurethane matrix except for carbon black [4].

Carbon black is an organic material and exists in a form of very fine particles with amorphous molecular structure [4]. It has emerged as another promising material as reinforcement due to its high aspect ratio, low cost, availability, easy to produce in fine particle sizes, low density and compatible with organic materials $[5,6,7]$. Apart from that, carbon black is a very effective reinforcement because it posseses a surface that has the ability to form strong attachment to polymeric matrix [7]. About $90 \%$ of carbon black produced in the world is used in the tyre industry to improve the tear strength, wear characteristics and modulus of tyres [7]. Many studies have been conducted by researchers involving the addition of carbon black to enhance the physical and mechanical properties of polymers. A study conducted by Marhoon produced polyurethane composites reinforced with carbon black that has increased tensile, impact, flexural and hardness of polyurethane [5].

Dumping of waste tyres is one of the persistent environment and economic problem in most countries [8]. There is a rapid development in transportation industry which causes a high demand for tyres. Over time, the tyres used will become worn and dumped which resulted in an increasing environmental problem. However, the utilisation of advancement in technology makes the disposal of waste tyres become easier. One of the technology that can be used to dispose waste tyres is pyrolysis which gives waste carbon tyres (WCT) as the end product. WCT provides an alternative to commercial carbon black as reinforcing filler in various polymer fabrication [9]. The advantages of using WCT over commercial carbon black are reduction in compounding cost and minimizing the environmental concern regarding dumping of waste tyres [10].

Hence, the main objective of this study is to investigate the effect of WCT loading on physical, rheological, mechanical, morphology and thermal properties of castor-based polyurethane composite.

\subsection{METHODOLOGY}

\subsection{Materials}

Castor oil (OH value: $161.62 \mathrm{mg} / \mathrm{KOH})$ was obtained from Progressive Scientific Sdn. Bhd. (Taman Batu, Jalan Batu Caves, Selangor). Isocyanate (4,4methylenediphenyl diisocyanate) with NCO content: 31\%, molecular weight: 360 was supplied by Growchem Sdn. Bhd. (Jln Mega 2/1, Semenyih, Selangor). The blowing agent (1,1-dichloro-1fluoroethane) was obtained from Airgas USA while pentamethyldipropylenatriamine (PMDETA) and dimethylcetylhexamine (DMCHA) were supplied by Huntsman (Singapore) Pte. Ltd. The surfactant (polyalkyleneoxidemethylsiloxane copolymer) was manufactured by Momentive Amer Ind (JIn Raja Laut, Chow Kit, Kuala Lumpur). PMDETA acts as blowing catalyst while DMCHA acts as gelling catalyst. The waste carbon tyres (WCT) composed of carbon (80.13wt\%), sulphides (6.05wt\%) and zinc oxide (7.83wt\%) was obtained from Ecopower Synergy Sdn. Bhd. (Bandar Puchong Jaya, Puchong, Selangor).

\subsection{Preparation of CPUC}

Castor-based polyurethane composites (CPUC) were prepared by adding waste carbon tyres (WCT) into neat castor-based polyurethane with $\mathrm{NCO}: \mathrm{OH}$ ratio of 2.6:1 [11]. Table 1 shows the formulation of CPUC. The loading of WCT was varied at $0 \%, 2 \%, 4 \%, 6 \%$. The carbon was first sieved to get uniform size of $200 \mu \mathrm{m}$ and dried in the oven for 24 hours at $70^{\circ} \mathrm{C}$ before being added into formulations prior to moisture elimination [12]. The first step in fabrication of CPUC was by mixing the polyol, blowing agent, surfactant and catalyst together using mechanical stirrer for about 2 minutes at $3000 \mathrm{rpm}$. WCT was then added into the mixture and stirred at $200 \mathrm{rpm}$ until the mixture was completely homogenous. The mixture was stirred at low speed to avoid WCT from being splattered around. Afterward, the speed of the mechanical stirrer 
was increased to $600 \mathrm{rpm}$ and the mixture was stirred for about 1 minute to ensure uniform and efficient dispersion of WCT in CPUC matrix. Then, isocyanate was added into the mixture and mixed at $3000 \mathrm{rpm}$ for about 20 seconds. After that, the mixture was poured and moulded in acrylic mould and conditioned at room temperature for about 24 hours to allow the curing and hardening of CPUC [13]. CPUC was demoulded and conditioned at room temperature for about 36 hours before being tested to enable CPUC to be fully cured.

Table 1 CPUC formulation

\begin{tabular}{cc}
\hline Samples & Waste carbon tyres loading (wt\%) \\
\hline CPUC0 & 0 \\
CPUC2 & 2 \\
CPUC4 & 4 \\
CPUC6 & 6 \\
\hline
\end{tabular}

\subsection{Characterizations and Testing}

Castor-based polyurethane composite (CPUC) was characterized and tested using the following methods:

a. Foam reaction time such as cream time, rise time and tack free time of CPUC were determined according to method ASTM D7487-13.

b. The apparent density of CPUC was determined according to method BS: Part 1: 1988 Method 2 which involved the measurement of CPUC that was let to free rise in a plastic cup.

c. The rheology properties of CPUC were determined by pouring mixture into a clear hose with a diameter of $10 \mathrm{~mm}$ and was let to flow down the hose until it stopped flowing and expanding. Then, the rheology index of CPUC was calculated according to the recorded flow distance and total weight of CPUC used [14].

d. Compression strength of CPUC was determined according to ASTM D 395 method B using Shimadzu Universal Compression Testing machine with crosshead speed movement of $50 \mathrm{~mm} / \mathrm{min}$ and sample dimension of $50 \times 50 \times 50 \mathrm{~mm}$.

e. Field-emission scanning electron microscopy (FESEM) was conducted on CPUC according to ASTM E 2089 method with 50X magnification. CPUC composites surface was coated with about $10-20 \mathrm{~nm}$ of gold layer before the analysis started and the cell morphology of CPUC composites was examined.

f. Thermogravimetric analysis (TGA) was conducted according to ASTM El 131 method using NETZSCH thermogravimetric analyser to evaluate the thermal stability of CPUC composites. The composites were tested at heating rate of $10^{\circ} \mathrm{C} / \mathrm{min}$, under air atmosphere with a flow rate of $60 \mathrm{ml} / \mathrm{min}$ and temperature range between room temperature to $800^{\circ} \mathrm{C}$ to ensure the completion of degradation of elements in CPUC.

\subsection{RESULTS AND DISCUSSION}

\subsection{Foam Reaction Time}

The fabrication of CPUC involved exothermic reaction between polyol and isocyanate and it influenced the foaming reaction of CPUC. Table 2 shows the effect of different WCT loading in CPUC on foam reaction time.

Table 2 CPUC reaction time

\begin{tabular}{cccc}
\hline Samples & $\begin{array}{c}\text { Cream time } \\
(\mathbf{s})\end{array}$ & $\begin{array}{c}\text { Rise time } \\
(\mathbf{s})\end{array}$ & Tack free time (s) \\
\hline CPUC0 & 4 & 280 & 475 \\
CPUC2 & 3 & 150 & 330 \\
CPUC4 & 4 & 250 & 380 \\
CPUC6 & 4 & 340 & 425 \\
\hline
\end{tabular}

Cream time is defined as the time interval between the mixing of mixture until it starts foaming [15]. The cream time for all types of composites is at $4 \mathrm{~s}$ except for CPUC2. The incorporation of WCT which acted as nucleation site enhancing the formation of cellular foams in CPUC2 [16]. This caused the increased of the foaming rate of CPUC2 resulted short cream time of CPUC2. However, further increased in WCT loading did not change the cream time of CPUC4 and CPUC6 where it remain constant at $4 \mathrm{~s}$. This was because the growth of cellular foams were hindered by the increased of viscosity of the mixtures [17]. These led to the constant cream time of CPUC2 and CPUC4. The overall range of cream time of CPUC is in the range of $3 \mathrm{~s}$ to $4 \mathrm{~s}$. This concurs well with previous findings by Suleman et al. [18] which reported the cream time of rigid polyurethane foam was in the range between $2 \mathrm{~s}$ to $7 \mathrm{~s}$.

The rise time is defined as the time interval between the end mixing of the mixtures until the completion of foaming reaction of the samples [15]. 2wt\% of WCT loading increased the reaction rate of CPUC2 resulting a shorter rise time. This was due to the presence of additional groups in WCT which incorporated into CPUC that led to the increment of exothermic reaction. These caused more heat evaporated enhancing the formation of cellular foams in CPUC matrix [16]. However, the increased of WCT loading by $4 \mathrm{w}+\%$ and $6 \mathrm{w}+\%$ caused the increment in the viscosity of CPUC4 and CPUC6. This was due to the high content of WCT that caused carbon agglomeration which reduced the foam reaction rate and phase separation in CPUC matrix. The presence of WCT also reduced the mobility of molecules which prolonged the rise time of CPUC [16]. The overall range of rise time for CPUC was between 150s to 340s. The values obtained were in agreement with commercial polyurethane grout processing conditions where the rise time was in the range of 110-460 s [19].

Tack free time is defined as the time taken for CPUC to lose the stickiness at the outer skin of the foam produced [20]. The addition of WCT gave a shorter tack free time to CPUC2, CPUC4 and CPUC6 
compared to neat CPUC. This indicated that WCT may acted as the curing accelerator which speed up the curing of the composites [16]. However, the tack free time of CPUC increased with increasing WCT loading. The increase of WCT loading caused the increment of particles in CPUC matrix. This caused the mobility of particles to decrease causing the agglomeration of WCT [21]. The presence of WCT agglomerate in CPUC matrix disturbed the crosslinking of $\mathrm{NCO}$ and $\mathrm{OH}$ group which caused the unreacted NCO group to be exposed on free surfaces [20]. This led to the stickiness and prolonged tack free time of CPUC. The overall tack free time of CPUC was in the range of 330 s to 425 $\mathrm{s}$. The values obtained were in agreement with commercial polyurethane grout properties where tack free time values were in the range of 140-470s [22].

\subsection{Apparent Density}

Apparent density is defined as the overall density of CPUC including its skin [23]. Apparent density is one of the key factors that influences the physical and mechanical properties of CPUC. This is because the apparent density represents the arrangement of cellular structure in CPUC matrix, which affect the strength of CPUC. Figure 1 shows the effect of WCT loading in apparent density of CPUC. The introduction of $2 \mathrm{wt} \%$ of WCT increased the apparent density of CPUC from $221.1 \mathrm{~kg} / \mathrm{m}^{3}$ to $262.9 \mathrm{~kg} / \mathrm{m}^{3}$ where the increment was by $18.91 \%$. Further WCT loading by $4 \mathrm{w}+\%$ and $6 \mathrm{wt} \%$ also resulted in the increase of apparent density of CPUC. WCT that was incorporated in CPUC promoted the formation of cell foams in CPUC matrix. This was because WCT acted as nucleation site for cellular foams formation which resulted in uniform distribution of cellular foams [16]. This led to the increment of interaction between the cellular foams in CPUC matrix. The increment in WCT loading also caused the cellular foams arrangement in CPUC matrix to become more compact, resulting in an increase in the apparent density of CPUC [24]. The increase of apparent density was also attributed to the increasing WCT content in CPUC, which led to the increase of total weight of CPUC.

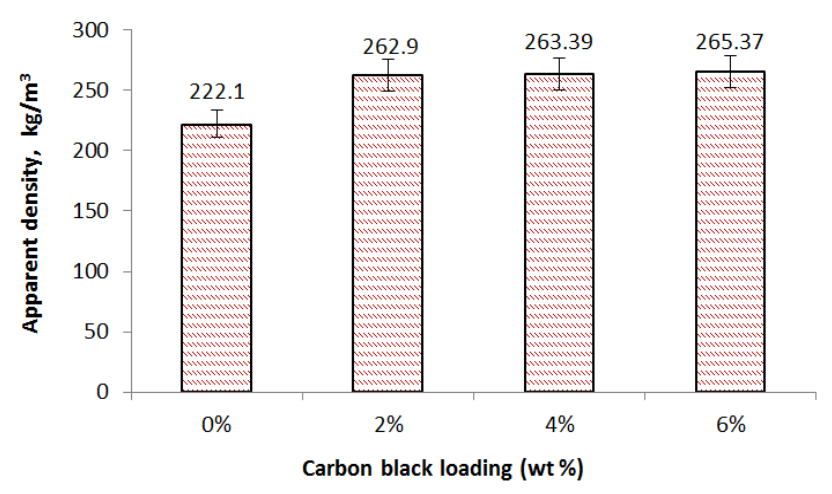

Figure 1 Apparent density of CPUC

\subsection{Rheology Properties}

The rheology test was conducted to identify the ability of CPUC to expand. The determination of rheology index of CPUC is one of the important factor to be considered in determining the ability of CPUC to fill the crack and hole that formed in infrastructures. Figure 2 shows that the introduction of $2 \mathrm{wt} \%$ of WCT decreased the rheology index of CPUC2 where it decreased from $2.43 \mathrm{~cm} / \mathrm{g}$ to $2.28 \mathrm{~cm} / \mathrm{g}$. The increment of WCT loading by $4 \mathrm{w}+\%$ and $6 \mathrm{w}+\%$ resulted in a steady decrease in the rheology index of CPUC. This is attributed to the increasing viscosity of mixtures, which reduced the foaming of CPUC [25]. The decrement in foaming reaction reduced the expansion of $\mathrm{CPUC}$, hence resulting in a decrease in rheology index [25]. Despite that, the rheology index obtained for CPUC was in agreement with a previous study conducted by Zhang et al. [26] which reported that the rheology index for polyurethane grouting materials produced in their research were in the range of between $0.4 \mathrm{~cm} / \mathrm{g}$ to 5 $\mathrm{cm} / \mathrm{g}$.

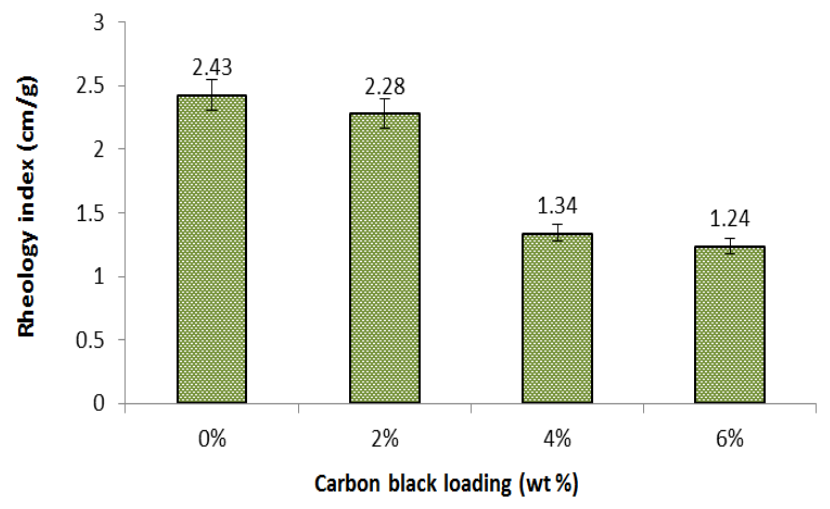

Figure 2 Rheology of CPUC

\subsection{Compression Properties}

The compression strength of CPUC depends on the cell foams morphology. Figure 3 shows the compression strength of CPUC.

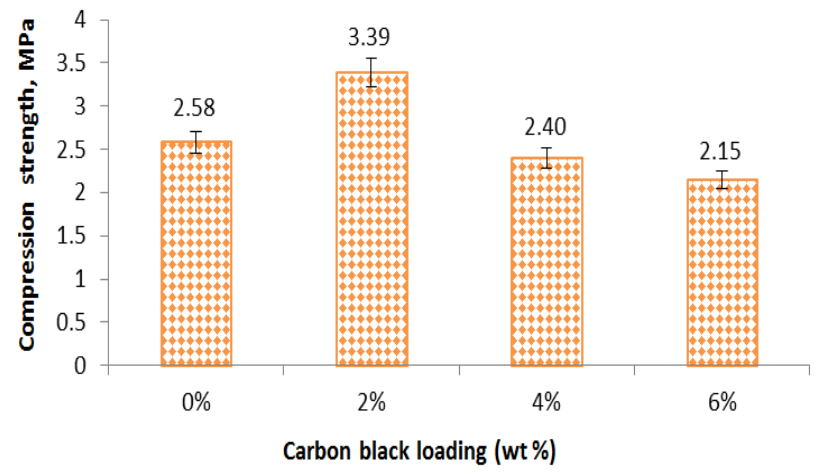

Figure 3 Compression strength of CPUC 
Based on Figure 3, the addition of $2 \mathrm{wt} \%$ of WCT in CPUC matrix caused an improvement in compression strength where the improvement was by $31.40 \%$. The introduction of WCT gave CPUC2 a more uniform size and distribution of cellular foams in CPUC2 matrix compared to neat PU. This was because WCT acted as nucleation site for cellular formation that controlled the growth of cellular foams in CPUC matrix [16]. The uniform size and distribution of cellular foams in CPUC2 matrix contributed to the increment in cell's surface contact area resulting in improvement of compression strength of CPUC2 [9]. The increment of compression strength of CPUC2 was closely related to the increment of apparent density of composites [15]. This was because the increase in apparent density of CPUC2 was related to the increase of compaction arrangement of cellular structures in CPUC2, resulting in a higher compression strength [27]. However, the addition of $4 \mathrm{wt} \%$ and $6 \mathrm{wt} \%$ of WCT caused the compression strength of CPUC to decrease to 2.40 $\mathrm{MPa}$ and $2.15 \mathrm{MPa}$ respectively. This was due to the poor dispersion and non-uniform distribution of WCT ( $4 \mathrm{wt} \%$ and $6 \mathrm{wt} \%$ ) in the mixtures which contributed to the embrittlement of cell foam walls, leading to their rupture and formation of distorted cell foams [28, 29, 30]. Surface contact area of the cell foams decreased due to distorted structure of cell foams, which caused the resistance of CPUC4 and CPUC6 to fracture under decreasing load, thus reducing the compression strength of composites.

Despite that, the compression strength obtained by CPUC concurs well with commercial polyurethane grouts' properties with densities in the range of 100 to $300 \mathrm{~kg} / \mathrm{m}^{3}$ and compression strength in the range of 1 to $5 \mathrm{MPa}$ [25]. Based on the result obtained, CPUC2 has optimum compression strength and exhibited the

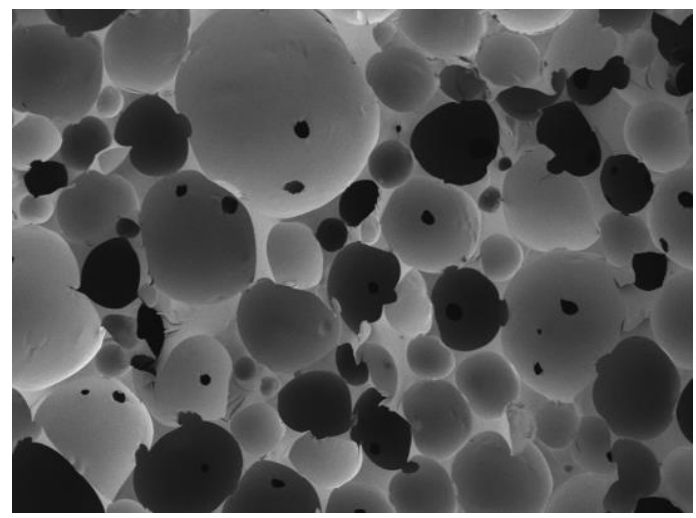

(a) CPUCO highest potential to be used as grouting material in the construction industry.

\subsection{Morphological Properties}

The cell foam morphology of CPUC is one of the most important factors in determining the mechanical properties of CPUC [25]. This is because through FESEM micrograph, the formation, distribution and dispersion of cell foams and WCT can be observed. It can be used to explain the mechanical properties achieved by CPUC. A fractured CPUC from bending test was used in determining its morphological properties. Based on the morphological structure of CPUC in Figure 4(a), (b), (c), (d), CPUC appeared to have closed cell of foam with polyhedral shape [20]. The exothermic reaction between isocyanate and polyol caused the evaporation of blowing agent, which then resulted in the formation of small closed cell of foam in CPUC matrix [31]. The addition of $2 \mathrm{wt} \%$ of WCT resulted in uniform size and distribution of cell foams. The uniform cell foams diameter contributed to a better interfacial adhesion and interaction between the cell foams in CPUC matrix, hence promoting the compression strength of CPUC [25]. However, the addition of $4 \mathrm{wt} \%$ and $6 \mathrm{Wt} \%$ of WCT resulted in a nonuniform size of cell foams in CPUC matrix [Figure 4(c), (d)]. Figure 4(d) shows that the cell foams of CPUC6 had an uneven distribution and unstable cell foams structure as the cell foams had distorted cell structures. This was attributed to the higher WCT loading which increased the viscosity of mixtures and gave a nonuniform dispersion of WCT in CPUC matrix [25]. This caused the collapsion of cell foams.

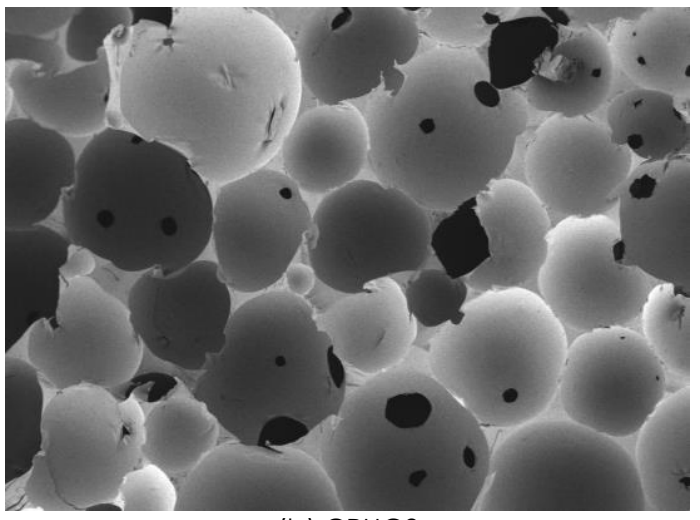

(b) CPUC2 


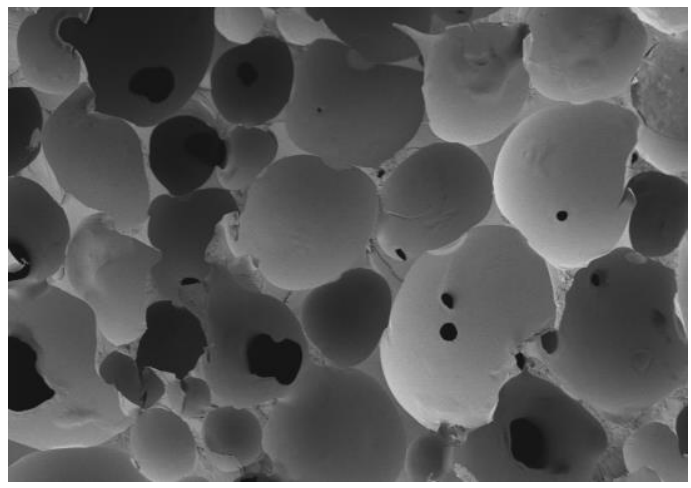

(c) CPUC4

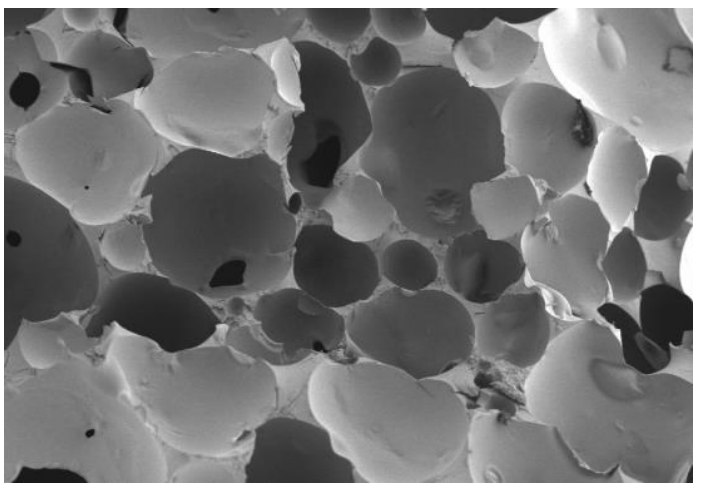

(d) CPUC6

Figure 4 Field emission scanning electron micrographs of castor based PU composites (CPUC)

\subsection{Degradation Behaviour}

Thermogravimetric analysis (TGA) was conducted to determine the effect of WCT loading on thermal stability of CPUC. Figure 5(a) and 5(b) show thermal degradation curve while Table 3 shows the decomposition data for CPUC samples. Three stages of thermal decomposition take place in CPUC. The first stage is attributed to the evolution of moisture and volatile element's presence in CPUC $\left(289^{\circ} \mathrm{C}\right.$ to $340^{\circ} \mathrm{C}$ ). The volatile product present in CPUC is the physical blowing agent used (HCFC). It is released as the dominant product in the first degradation stage [31]. The second stage $\left(340^{\circ} \mathrm{C}\right.$ to $\left.440^{\circ} \mathrm{C}\right)$ is attributed to the breaking of urethane bond and decomposition of polyol in CPUC, while the third stage $\left(440^{\circ} \mathrm{C}\right.$ to $\left.550^{\circ} \mathrm{C}\right)$ is attributed to the decomposition of isocyanate.

The addition of $2 \mathrm{wt} \%$ of WCT into CPUC resulted in a slight drop in $\mathrm{T}_{1}$ onset temperature where the temperature dropped from $293.1^{\circ} \mathrm{C}$ to $289.4^{\circ} \mathrm{C}$. This was probably due to the presence of moisture in WCT that lowered $T_{1}$ onset temperature of CPUC2 [25]. However, $\mathrm{T}_{2}$ onset temperature of CPUC2 increased. This was attributed to the role of WCT, which acted as insulator preventing the heat from spreading out, reducing the breakage of urethane bond and decomposition of polyol in CPUC [32].

The addition of $4 \mathrm{w}+\%$ of WCT resulted in a decrease in $T_{2}$ onset temperature. This was due to higher WCT loading which caused poor dispersion of WCT in CPUC matrix. This enabled the heat to spread, breaking down the urethane linkages hence resulting in a decrement in thermal stability of CPUC4 [33].

Char residue content at $800^{\circ} \mathrm{C}$ is attributed to the elements that do not degrade at high temperature. The addition of $2 \mathrm{wt} \%$ of WCT increased the char residue content from $6.50 \%$ to $10.22 \%$. The increase in char residue of CPUC2 is attributed to the increment in formation of stable char layer, which leads to the increasing thermal stability of CPUC [33]. For CPUC with $4 \mathrm{wt} \%$ and $6 \mathrm{wt} \%$ of WCT loading, the char residue content decreased. This was probably due to the high content of WCT which caused agglomeration of WCT [5]. The presence of agglomeration in CPUC reduced the barrier properties of WCT, resulting in an increase of heat transfer in CPUC. This caused an increase in weight loss of CPUC, resulting in lower char residue of CPUC4 and CPUC6.

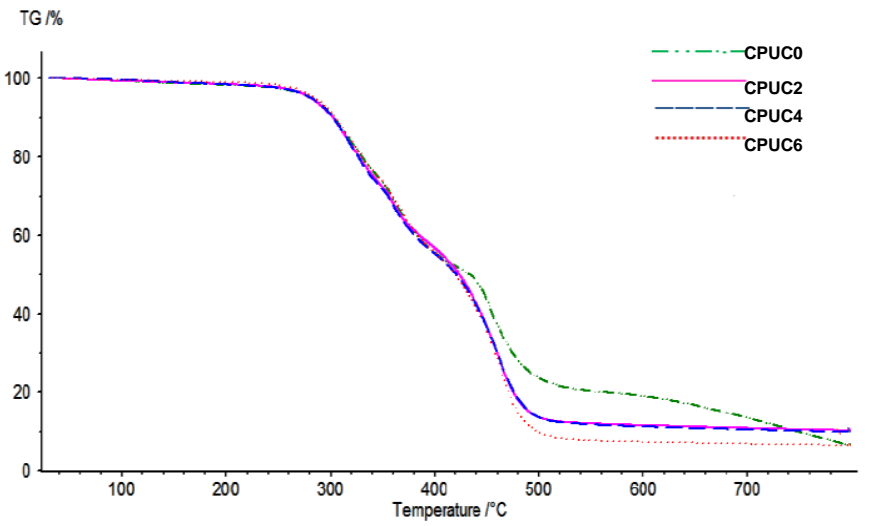

(a) TGA curves

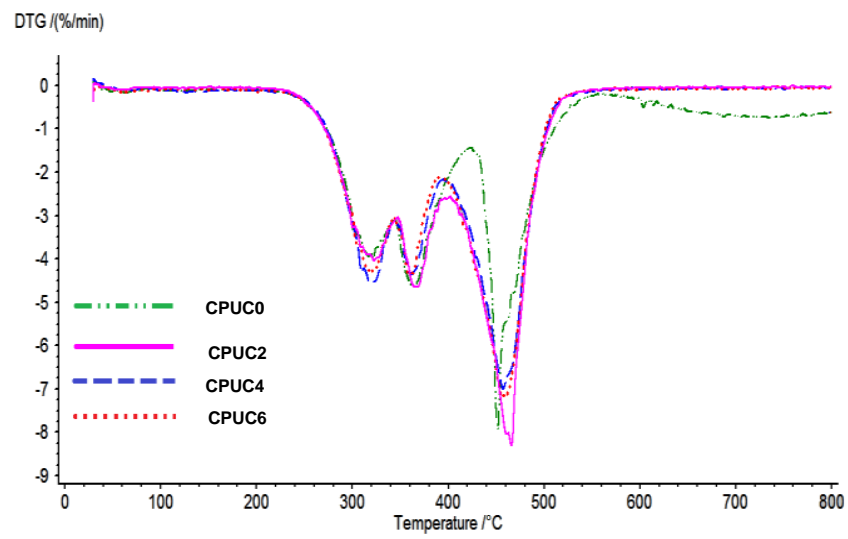

(b) DTG curves

Figure 5 Castor-based polyurethane composites thermogram 
Table 3 Thermal properties of CPUC

\begin{tabular}{|c|c|c|c|c|c|c|c|}
\hline \multirow[t]{3}{*}{ Samples } & \multicolumn{6}{|c|}{ Degradation temperature $\left({ }^{\circ} \mathrm{C}\right)$} & \multirow{3}{*}{$\begin{array}{c}\text { Char residue at } \\
800^{\circ} \mathrm{C}(\%)\end{array}$} \\
\hline & \multicolumn{2}{|c|}{$1^{\text {st }}$ step } & \multicolumn{2}{|c|}{$2^{\text {nd }}$ step } & \multicolumn{2}{|c|}{$3^{\text {rd }}$ step } & \\
\hline & $T_{1}$ onset & $T_{1 \max }$ & $T_{2}$ onset & $\mathrm{T}_{2 \max }$ & $T_{3}$ onset & $T_{3 \max }$ & \\
\hline CPUCO & 293.1 & 344.1 & 346.2 & 423.4 & 441.5 & 560.6 & 6.50 \\
\hline CPUC2 & 289.4 & 326.1 & 347.1 & 401.5 & 411.8 & 562.4 & 10.22 \\
\hline CPUC4 & 295.9 & 330.1 & 342.7 & 394.7 & 412.2 & 540.3 & 9.86 \\
\hline CPUC6 & 290.5 & 342.6 & 344.0 & 390.8 & 419.4 & 563.8 & 6.55 \\
\hline
\end{tabular}

\subsection{CONCLUSION}

Castor-based polyurethane filled with waste carbon tyres with excellent properties for grouting application was successfully produced. In conclusion, the rise time and tack free time of CPUC increased with increasing WCT loading. The apparent density of CPUC increased with increasing WCT loading with CPUC6 having the optimum apparent density with a value of $265.7 \mathrm{~kg} / \mathrm{m}^{3}$. The rheological properties of CPUC decreased with increasing WCT loading. The introduction of $2 \mathrm{wt} \%$ of WCT improved the compression strength of CPUC2 by $31.40 \%$ and gave the optimum value. The compression strength achieved by CPUC was in the range of industrial polyurethane grout's compressive properties. At the same time, the addition of 2 wt\% of WCT also improved the thermal stability of CPUC and gave the optimum thermal stability as it had the highest amount of char residue which was $10.22 \%$ compared to other CPUC samples.

\section{Acknowledgement}

The authors acknowledge International Polyurethane Technology Foundation for International Grant Scheme 100-IRMI/INT/ 16/6/2 (004/2018) and Universiti Teknologi MARA for the research facilities.

\section{References}

[1] Clemitson, I. R. 2015. Castable Polyurethane Elastomers. CRC Press.

[2] Yang, Z., Zhang, X., Liu, X., Guan, X., Zhang, C., and Niu, Y. 2017. Flexible and Stretchable Polyurethane/Waterglass Grouting. Material Construction and Building Materials. 138: $240-245$.

DOI: http://dx.doi.org/10.1016/j.conbuildmat.2017.01.113.

[3] Bodi, J., Bodi, Z., Scucka, J., and Martinec, P. 2012. Polyurethane Grouting Technologies. Polyurethane. 307337.

DOI: http://dx.doi.org/10.5772/35791.

[4] Xiong, L. W. and Badri, K. 2018. Preparation of Polyurethane Composites with Activated Carbon Black as the Reinforcing Filler. Journal of Polymer Science and Technology. 3(1): 11-18.

[5] Marhoon, I. I. 2017. Mechanical and Physical Properties of Polyurethane Composites Reinforced with Carbon Black
N990 Particles. International Journal of Scientific \& Technology Research. 6(12): 225-228.

[6] Komameni, S. 1992. Nanocomposites. Journal of Materials. Chemistry. 2(12).

[7] Rothon, R. N. 2002. Particulate Fillers for Polymers. Vol. 12. United Kingdom: iSmithers Rapra Publisher.

[8] Miandad, R., Barakat, M. A., and Aburiazaiza, A. A. 2017. Effect of Plastic Waste Types on Pyrolysis Liquid Oil. International Journal of Biodeterioration \& Biodegradation. 119: 239-252.

[9] Fakhar, A. M. and Asmaniza, A. 2016. Road Maintenance Experience Using Polyurethane (PU) Foam Injection System and Geocrete Soil Stabilization as Ground Rehabilitation. IOP Conference Series: Materials Science and Engineering. 136

DOI: http://dx.doi.org/10.1088/1757-899X/136/1/012004.

[10] Ismawi, D. D. A., Zaeimoedin, T. Z., and Saad, C. S. M. 2010. Recovered Carbon Black From Waste Tyres: Effect on Mechanical Properties of Rubber Compound. Conference Malaysian Science and Technology Congress (MSTC), 2010. Selangor, Malaysia. November 2010, 1-11. DOI: http://dx.doi.org/10.13140/RG.2.1.4274.6482.

[11] Hussain, N. I. A. M., Bonnia, N. N., Hirzin, R. S. F. N., Ali, E. S., and Zawawi, E. Z. E. 2019. Effect of $\mathrm{NCO} / \mathrm{OH}$ Ratio on Physical and Mechanical Properties of Castor-based Polyurethane Grouting Materials. Journal of Physics: Conference Series. 1349: 012-113. DOl: $h t t p: / / d x . d o i . o r g / 10.1088 / 1742-6596 / 1349 / 1 / 012113$.

[12] Khalil, H. A., Noriman, N. Z., Ahmad, M. N., Ratnam, M. M., and Fuaad, N. N. 2007. Polyester Composites Filled Carbon Black and Activated Carbon from Bamboo (Gigantochloa Scortechinii): Physical and Mechanical Properties. Journal of Reinforced Plastics and Composites. 26(3): 305-320.

DOI: http://dx.doi.org/10.1177/0731684407065066.

[13] E. S. Ali and S. A. Zubir. 2016. The Mechanical Properties of Medium Density Rigid Polyurethane. MATEC Web of Conference. 39: 1-5.

DOI: http://dx.doi.org/10.1051/matecconf/20163901009.

[14] Ali, E. S. 2008. Biokomposit Hibrid Poliuretana Berasaskan Minyak Kelapa Sawit Berpengisi Nanozarah OrganoMonmorilonit dan Serabut Tandan Kosong Kelapa Sawit. Thesis dissertation. Universiti Kebangsaan Malaysia.

[15] Francés, A. B. and Banon, M. N. 2014. Effect of Silica Nanoparticles on Polyurethane Foaming Process and Foam Properties. IOP Conference Series: Materials Science and Engineering. 64(1).

DOI: http://dx.doi.org/10.1088/1757-899X/64/1/012020.

[16] Strakowska, A., Członka, S., and Strzelec, K. 2019. POSS Compounds as Modifiers for Rigid Polyurethane Foams (Composites). Polymers. 11 (7): 1092.

DOI: http://dx.doi.org/10.3390/polym1 1071092

[17] Song, Z. L., Ma, L. Q., Wu, Z. J. and He, D. P. 2000. Effects of Viscosity on Cellular Structure of Foamed Aluminum in Foaming Process. Journal of Materials Science. 35: 15-20. DOI: http://dx.doi.org/10.1016/j.indcrop.2014.11.053.

[18] Suleman, S., Khan, S. M., Jamil, T., Aleem, W., Shafiq, M., and Gull, N. 2014. Synthesis and Characterization of 
Flexible and Rigid Polyurethane Foam. Asian Journal of Applied Sciences. 2(5).

[19] Alchemy-Spetec. Retrieved from https://alchemyspetec.com/up-content/uploads/03-64-01-InjectionGrouting-Hydrophilic-and-Hydrophobic.pdf

[20] Kim, S. H., Kim, B. K. and Lim, H. 2008. Effect of Isocyanate Index on the Properties of Rigid Polyurethane Foams Blown By HFC 365mfc. Macromolecular Research. 16(5): 467-472. DOI: http://dx.doi.org/10.1007/BF03218546.

[21] Jassim, M. S. 2015. Studying Some Properties of Unsaturated Polyester Composite Reinforced by Carbon Black Particulate. Journal of University of Babylon. 23(2): 271-275.

[22] SikaFix $\mathrm{HH}$ Hydrophilic. Retrieved from https://usa.sika.com/en/construction/department oftransportation/grouts/polyurethane-grouts/sikafix-hhhydrophilic.html.

[23] Wei, Y., Wand, F., Gao, X., and Zhang, Y. 2017. Microstructure and Fatigue Performance of Polyurethane Grout Materials under Compression. Journal of Materials in Civil Engineering. 29(9).

[24] Wypych, G. 2017. Handbook of Foaming and Blowing Agents. Canada: ChemTec Publishing.

[25] Mosiewicki, M. A., Arciprete, G. A. D., Aranguren, M. I., and Marcovich, N. E. 2009. Polyurethane Foams Obtained From Castor Oil-based Polyol and Filled with Wood Flour. Journal of Composite Materials. 43(25): 3057-3072.

[26] Zhang, Q., Hu, X. M., Wu, M. Y., Zhao, Y. Y., and Yu, C. 2018. Effects of Different Catalysts on the Structure and Properties of Polyurethane/Water Glass Grouting Materials. Journal of Applied Polymer Science. 135(27): 460-464.

DOI: http://dx.doi.org/10.1002/app.46460
[27] Hamilton, A. R., Thomsen, O. T., Madaleno, L. A., Jensen, L. R., Rauhe, J. C. M., and Pyrz, R. 2013. Evaluation of the Anisotropic Mechanical Properties of Reinforced Polyurethane Foams. Composite, Science Technology. 87: 210-217.

[28] Qi, X., Zhang, Y., Chang, C., Luo, X., and Li, Y. 2018. Thermal, Mechanical, and Morphological Properties $\mathrm{O}=\mathrm{of}$ Rigid Crude Glycerol-Based Polyurethane Foams Reinforced with Nanoclay and Microcrystalline Cellulose. European Journal of Lipid Science and Technology. 120(5).

[29] Saint-Michel, F., Chazeau, L., and Cavaillé, J. Y. 2006. Mechanical Properties of High Density Polyurethane Foams: II Effect of the Filler Size. Composites Science and Technology. 66(15): 2709-2718.

[30] Maharsia, R. R. and Jerro, H. D. 2007. Enhancing Tensile Strength and Toughness in Syntactic Foams through Nanoclay Reinforcement. Materials Science and Engineering. 454: 416-422. DOl: http://dx.doi.org/10.1016/j.msea.2006.11.121.

[31] Shutov, F. A. 1991. Cellular Structure and Properties of Foamed Polymers. Handbook of Polymeric Foams and Foam Technology. 17-46.

[32] Bera, T., Acharya, S. K., and Mishra, P. 2018. Synthesis, Mechanical and Thermal Properties of Carbon Black/Epoxy Composites. International Journal of Engineering, Science and Technology. 10(4): 12-20.

[33] Sylwia, C., Anna, S., Krzysztof, S., Agnieszka, Adamus-W. Agne, K. and Saulius, V. 2019 Composites of Rigid Polyurethane Foams Reinforced with POSS. Polymers. 336(11). 